\title{
The conifer-curve: fast prediction of hydraulic conductivity loss and vulnerability to cavitation
}

\author{
Sabine Rosner ${ }^{1}$ (D) $\cdot$ Daniel M. Johnson $^{2} \cdot$ Klara Voggeneder $^{1} \cdot$ Jean-Christophe Domec ${ }^{3,4}$
}

Received: 31 January 2019 / Accepted: 23 July 2019 / Published online: 6 August 2019

(C) The Author(s) 2019

\begin{abstract}
- Key message The relationship between relative water loss (RWL) and hydraulic conductivity loss (PLC) in sapwood is robust across conifer species. We provide an empirical model (conifer-curve) for predicting PLC from simple RWL measurements. The approach is regarded as a new relevant phenotyping tool for drought sensitivity and offers reliable and fast prediction of diurnal, seasonal, or drought-induced changes in PLC.

- Context For conifer species drought is one of the main climate risks related to loss of hydraulic capacity in sapwood inducing dieback or mortality. More frequently occurring drought waves call for fast and easily applicable methods to predict drought sensitivity.

- Aims We aimed at developing a fast and reliable method for determination of the percent loss of hydraulic conductivity (PLC) and eventually the drought sensitivity trait $P_{50}$, i.e., the water potential that causes $50 \%$ conductivity loss.

- Methods We measured the loss of water transport capacity, defined as the relative water loss (RWL) together with PLC in trunk wood, branches, and saplings of eight different conifer species. Air injection was used to induce specific water potentials.

- Results The relationship between RWL and PLC was robust across species, organs, and age classes. The equation established allows fast prediction of PLC from simple gravimetrical measurements and thus post hoc calculation of $P_{50}\left(r^{2}=0.94\right)$.

- Conclusion The approach is regarded as a relevant new phenotyping tool. Future potential applications are screening conifers for drought sensitivity and a fast interpretation of diurnal, seasonal, or drought-induced changes in xylem water content upon their impact on conductivity loss.
\end{abstract}

Keywords Conifers $\cdot$ Drought stress $\cdot$ Hydraulic capacitance $\cdot$ Phenotyping $\cdot$ Vulnerability to cavitation

Handling Editor: Cyrille B. K. Rathgeber

Contribution of the co-authors: SR, KV, JCD, and DMJ performed the hydraulic measurements. SR made the data analysis and wrote a first draft of the manuscript. JCD and DMJ edited subsequent versions of the manuscript.

This article is part of the topical collection on Wood formation and tree adaptation to climate

Sabine Rosner

sabine.rosner@boku.ac.at

1 Institute of Botany, University of Natural Resources and Life Sciences, Gregor Mendel Str. 33, 1180 Vienna, Austria

2 Warnell School of Forestry and Natural Resources, University of Georgia, Athens, GA 30602, USA

3 Nicholas School of the Environment, Duke University, Durham, NC 27708, USA

4 Bordeaux Sciences Agro, UMR 1391 INRA-ISPA, 33175 Gradignan Cedex, France

\section{Introduction}

Conifers are among the most endangered plant groups regarding forest dieback related to drought (Solberg 2004; Hentschel et al. 2014; Allen et al. 2015; Mencuccini and Binks 2015; McDowell and Allan 2015; Rosner et al. 2018; Klein et al. 2019). According to the International Union for Conservation of Nature (IUCN Red List), 34\% of the world's conifers species are threatened (IUCN 2019). Facing global change (IPCC 2013), we urgently need fast and reliable screening tools for predicting drought sensitivity of conifer species and provenances thereof (David-Schwartz et al. 2016, Voltas et al. 2018). Screening tools should be economical, require little labor, not be time-consuming, easy in application and - last but not least - applicable to conifers worldwide. Recently, Rosner et al. (2019) presented an approach where hydraulic conductivity loss of angiosperm and conifer sapwood could be predicted from simple water loss measurements. The empirical predicting models in this preceding study were however species-specific. In the present study, we 
aimed at developing one single prediction curve that would be applicable for conifers with a wide range of natural occurrence. The idea for a conifer prediction model developed because the relationship between relative water loss and conductivity loss varied widely among angiosperm species; the curves of conifer species showed a quite stable relationship (Rosner et al. 2019). Research on this plant group was also continued because their wood structure allows quite short sample lengths and application of several methods to measure hydraulic vulnerability that exists so far (Cochard et al. 2013, Klein et al. 2018).

Hydraulic performance of (secondary) xylem under drought and its recovery from drought depends on (I) hydraulic vulnerability to embolism, expressed as, e.g., $P_{50}$ (i.e., the water potential resulting in 50\% conductivity loss), (II) hydraulic safety margins, which is the $P_{50}$ in relation to the minimum water potential measured in the field (Tyree and Sperry 1988, Choat et al. 2012; Delzon and Cochard 2014; Choat et al. 2018), and on (III) the capability of refilling emptied tracheids, which is presumably related to the hydraulic capacitance (Johnson et al. 2012; McCulloh et al. 2014; Trifilò et al. 2015, Klein et al. 2018 ), or (IV) the potential to produce new xylem tissue (Magnani and Borghetti 1995; Cochard et al. 2001). Water storage capacitance is the amount of water released from a tissue due to a defined decline in water potential (Tyree and Yang 1990; Meinzer et al. 2003; Domec et al. 2006). In general, more knowledge exists about species or organ-specific $P_{50}$ and the shape of vulnerability curves (Choat et al. 2012), i.e., the percent loss of conductivity (PLC) plotted against the water potential $(\Psi)$ (Sperry and Tyree 1988), than about hydraulic capacitance (Trifilò et al. 2015). Capacitance can be expressed as the increase in the absolute mass of water lost from a sample of defined volume per unit $\Psi$ change but also as the increasing relative water loss (RWL) per unit $\Psi$ change. The RWL method allows the comparison of the samples differing in total water volume and wood density (Domec and Gartner 2001). Rosner et al. (2019) defined an additional capacitance parameter, the RWL at $P_{50}$, i.e., the RWL that results from $50 \%$ conductivity loss. RWL at $P_{50}$ varies widely across angiosperm and conifer species and is negatively related to wood density, as found for other capacitance traits as well (Pratt et al. 2007; Scholz et al. 2007; McCulloh et al. 2014; Trifilò et al. 2015; Savi et al. 2017; Pratt and Jacobsen 2017).

The aim of this study was to confirm the quite stable relationship between PLC and RWL (Rosner et al. 2019) across conifers species originating from different ecosystems around the globe. Such an approach should not only result in a fast prediction of species-, organ-, or age class-specific hydraulic vulnerabilities but will also allow us to establish the amount water remaining in xylem at $P_{50}$ and $P_{88}$ ( $\Psi$ at $88 \%$ PLC). We tested mature and juvenile trunkwood as well as branches of eight different conifer species with a broad range of natural occurrence from extremely wet environments (Taxodium distichum) to quite dry environments (Juniperus virginiana). We thus expected a wide range in
$P_{50}$. Most of the species investigated are also of high economical importance (Abies nordmanniana, Larix decidua, Picea abies, Pinus ponderosa, Pinus taeda, Pseudotsuga menziesii) which further substantiates the need for fast and reliable screening tools for selecting appropriate provenances with a higher drought tolerance.

\section{Material and methods}

\subsection{Plant material}

Information on the origin of the plant material is provided in Table 1. Eight different conifer species were investigated, which comprised Abies nordmanniana ((Stev.) Spach), Juniperus virginiana L., Larix decidua Mill., Picea abies (L.) Karst., Pinus ponderosa P. Lawson and C. Lawson, Pinus taeda L., Pseudotsuga menziesii (Mirbel) Franco, and Taxodium distichum $\mathrm{L}$. Rich.

\subsection{Determination of conductivity loss and relative water loss}

Either whole saplings or side branches (cut from larger supporting branches with a length varying from 0.5 to $1.5 \mathrm{~m}$ ) were harvested in the morning and transported to the lab in black plastic bags containing wet towels. Internodes with a length of $200 \mathrm{~mm}$ were cut and debarked underwater. They were re-saturated under low vacuum for $24 \mathrm{~h}$ at $4{ }^{\circ} \mathrm{C}$ in filtered, distilled water (Hietz et al. 2008) with $0.005 \%$ Micropur (Katadyn Products, Wallisellen, Switzerland). Prior to hydraulic measurements, specimens were shortened to $130 \mathrm{~mm}$ and then re-cut several times with clean razor blades. Sapwood area hydraulic conductivity $\left(K \mathrm{~s}, \mathrm{~cm}^{2} \mathrm{~s}^{-1} \mathrm{MPa}^{-1}\right)$ was measured under a hydraulic pressure head of $5.4 \mathrm{kPa}(540 \mathrm{~mm}$ water column) with distilled and filtered $(0.22 \mu \mathrm{m})$ water containing $0.005 \%$ Micropur. The saturated weight (SW) was determined on a balance (resolution of $0.0001 \mathrm{~g}$, Mettler-Toledo International Inc., Greifensee, Switzerland). Air overpressure was applied in a double-ended pressure chamber (PMS Instruments, Corvallis, OR, USA), thereafter the specimen was weighed again in order to determine the fresh weight (FW) at a given pressure application. The pressure in the chamber was gradually increased with steps of $0.5 \mathrm{MPa}$ or 1.0 MPa. The duration of the pressure exposition was standardized to $1 \mathrm{~min}$ (Rosner et al. 2019). Hydraulic vulnerability curves of trunk wood samples were achieved with the methods described by Spicer and Gartner (1998) and Domec and Gartner (2001). Results on PLC and RWL at given pressure applications for $L$. decidua and P. abies came from existing datasets (Rosner et al. 2008, Rosner et al. 2019). Tangential and radial faces of 200-mm long wood beams with a transverse surface of $100 \mathrm{~mm}^{2}$ were shortened on a band saw and thereafter re-cut several times with a 
razor blade. Specimens were re-soaked as described above (Hietz et al. 2008). The final dimensions of the specimens were $6 \mathrm{~mm}$ (radial) $\times 6 \mathrm{~mm}$ (tangential) $\times 120 \mathrm{~mm}$ (longitudinal) .

Samples were dried at $103{ }^{\circ} \mathrm{C}$ for $24 \mathrm{~h}$ (Rosner 2017) in order to determine the dry weight (DW) on a balance. The relative water loss (RWL) at $\Psi$ was calculated as:

$\operatorname{RWL}(\%)=100 *(1-((\mathrm{FW}-\mathrm{DW}) /(\mathrm{SW}-\mathrm{DW})))$

The correct determination of the SW is crucial because relating FW to a field in situ water content would obscure the relationship between RWL and PLC and would not allow correct projection of PLC (Rosner et al. 2019).

\subsection{Sample numbers, data processing, and statistical analyses}

Numbers of sampled trees, samples and datasets can be found in Table 1. The software SPSSTM 21.0 was used to carry out the data analyses. Normal distribution was tested with the Kolmogorov-Smirnov test. Relationships between traits were accepted as significant if the $P$ value was $<0.05$.

Sapwood area-specific hydraulic conductivity at a given $\Psi$ was divided by the sapwood area-specific hydraulic conductivity at full saturation in order to calculate the percent loss of conductivity (PLC). PLC was plotted against the negative of the applied pressure $(\Psi)$. For some species, organs or age classes only mean values for PLC and RWL at a given pressure application were available. Hydraulic vulnerability curves were fitted by an exponential sigmoidal equation (Pammenter and Vander Willigen 1998), and the $P_{50}$ and $P_{88}$ (Domec and Gartner 2001), i.e., the pressure application at which $50 \%$ or $88 \%$ of conductivity loss occurred, were calculated. We used the following equation:

$\operatorname{PLC}(\%)=100 /(1+\exp (a *(\Psi-b)))$

The parameter " $a$ " corresponds to the slope of the linear part of the regression and " $b$ " is the $P_{50} . P_{88}$ was calculated from these parameters. $\Psi$ in Eq. (2) is used here and thereafter for water potential. In Table 2, results for " $a$ " and $P_{50}$ are provided with their standard error and the $95 \%$ confidence interval (CI 95\%).

The relationship between point measurements and mean PLC and RWL were tested by the "curve estimation" function in SPSSTM 21.0, where linear, quadratic, or cubic regressions were chosen according to their predictive quality. The chosen equation was used to calculate RWL at $P_{50}$ for each species, organ, or age class. In Table 3, the CI 95\% and 95\% individual prediction intervals (PI 95\%) for RWL at $P_{50}$ or RWL at $P_{88}$ are provided. Species, organ, and age class-specific mean values of PLC ( PLC $\left._{\text {pred }}\right)$ and RWL were fitted by a Weibull equation (e.g., Lopez et al. 2005):
$\operatorname{PLC}_{\text {pred }}=100-(100 /(\exp ((\mathrm{RWL} / c) * * d)))$

The parameter " $c$ " corresponds to the mean RWL across all conifers investigated in the study that causes $\sim 63 \%$ of PLC.

Water loss curves, i.e., the RWL plotted against $\Psi$ (RWL- $\Psi$ curve) were fitted by the "curve estimation" function in SPSSTM 21.0. The fittings with the highest predictive quality $\left(r^{2}\right)$ and the most reliable shape were chosen. The "curve estimation" function was also used to establish the relationship between $\Psi$ and RWL in order to predict $\Psi$ at a given RWL, for instance the RWL at $P_{50}$ or at $P_{88}$. In these curves, the $\Psi$ was plotted against the RWL ( $\Psi$-RWL curve, Table 4).

The predictive quality of the RWL for PLC at the species, organ and age class level was tested by calculating empirically modeled $P_{50}$ parameters from the RWL at $P_{50}$ and the relationship between $\Psi$ and RWL ( $\Psi$-RWL curve). The same procedure was performed for $P_{88}$. The predicted values of $P_{50}$ and $P_{88}$ are provided with their $95 \% \mathrm{CI}$ and $95 \%$ PI (Table 4). By means of the Eq. [3], PLC was predicted from RWL point measurements (if available) and mean values (Table 1). Thereafter, $P_{50}$ and $P_{88}$ parameters (Table 5) were calculated using Eq. [2]. Modeled $P_{50}$ and $P_{88}$ were related to the corresponding traits from directly measured datasets. Linear regression analysis was performed to meet the 1:1 slope requirement. A flow chart of the two different approaches is shown in Fig. 1.

\section{Results}

Conifer species investigated varied widely in their vulnerability to cavitation (Fig. 2, Table 2). In saplings, A. nordmanniana had the lowest $P_{50}(-8.1 \mathrm{MPa})$ and $P$. menziesii grown in Austria had the highest $P_{50}(-5.0 \mathrm{MPa})$. In branches, $P_{50}$ ranged from $-5.8 \mathrm{MPa}$ in $P$. menziesii to $-2.4 \mathrm{MPa}$ in $T$. distichum. In general, $P_{50}$ was highest in the wood of the main trunk, ranging from -4.9 MPa in P. menziesii to $-2.2 \mathrm{MPa}$ in $P$. abies. The species investigated varied as well in their RWL at a given pressure application (Fig. 2). For instance, whereas RWL increased only slightly with each pressure application in A. nordmanniana saplings (Fig. 2b), RWL had large increases over narrower pressure ranges in $P$. abies trunk wood (Fig. 2d).

PLC was strongly related to RWL at the species/organ/agespecific level (Table 3). Mean species/organ/age-specific PLC for a given $\Psi$ and PLC predicted from the corresponding RWL dataset (Table 3 ) were therefore strongly linearly related (Fig. $3 b)$. The RWL at $P_{50}$ had values ranging from $15 \%$ in $L$. decidua saplings to $36 \%$ in J. virginiana trunk wood. By means of the species/organ/age-specific RWL at $P_{50}$ and the relationship between $\Psi$ and RWL (Table 4), $P_{50}$ values could be predicted which correlated strongly (almost 1:1) with those calculated from the measured dataset (Fig. 4a). Predicted $P_{88}$ was 
as well strongly related to $P_{88}$ derived from measured datasets $\left(r^{2}=0.98, P<0.0001\right)$.

In order to guarantee equal weight of each species-, organ-, and age class-specific PLC-RWL relationship, mean values for a given $\Psi$ were used for the pooled data analysis (Fig. 3a). The relationship between PLC and RWL across all samples was fitted with the function:

$\operatorname{PLC}_{\text {pred }}=100-(100 /(\exp ((\mathrm{RWL} / 30.49) * * 1.92)))($ conifer-curve $)$

$\mathrm{PLC}_{\text {pred }}$ is the predicted percent loss of hydraulic conductivity (Fig. 3c). More information on the parameters of Eq. (4) can be found in the legend of Fig. 3. RWL of $30.49 \%$ corresponds to a $\mathrm{PLC}_{\text {pred }}$ of $\sim 63 \%$ across all conifer specimen investigated. RWL of $25.18 \%$ would then result in PLC $_{\text {pred }}$ of $50 \%$, and RWL of $45.12 \%$ would result in PLC $_{\text {pred }}$ of $88 \%$ across species, organs, and age classes.

From RWL point measurements and the conifer-curve, $\mathrm{PLC}_{\text {pred }}$ values were calculated. PLC $\mathrm{C}_{\text {pred }}$ values and the corresponding $\Psi$, was used to project $P_{50}$ (Table 5). The correlation between $P_{50}$ and the empirically modeled $P_{50}\left(P_{50 \text { pred }}\right)$ was tight $\left(r^{2}=0.94, P<0.0001\right)$, but no 1:1 relationship could be reached for specimens with low $P_{50}$ (Fig. 6, in the Annex). A linear regression was therefore used for reliably predicting $P_{50}$ (Fig. 4b).

$P_{50 \text { pred }}=-0.75+0.82 * P_{50 \text { pred }}\left(r^{2}=0.97, P<0.0001\right)$

where $P_{50 \text { pred }}$ ' corresponds to $P_{50 \text { pred }}$ after slope correction. $P_{88 \text { pred }}$ was as well strongly related to $P_{88}$ calculated from measured data $\left(r^{2}=0.98, P<0.0001\right)$.

Conifer species, organs or age classes with higher RWL at $P_{50}$ or $P_{88}$ were more vulnerable to cavitation: The positive relationship with $P_{50}$ was however much stronger with RWL at $P_{88}$ (Fig. 5). $P_{88}$ showed as well an increase with increasing RWL at $P_{88}\left(r^{2}=0.44, P<0.01\right)$.

Flow \& mass at full saturation

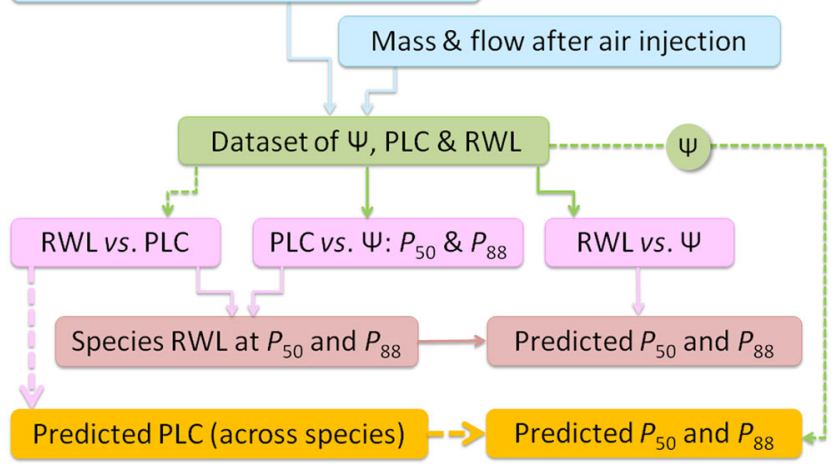

Fig. 1 Flow chart of the measuring procedure for the two model approaches for calculating the $P_{50}$ or $P_{88}$. Hatched lines indicate the modeling procedure for the "conifer curve", solid lines for the speciesspecific modeling approach to predict $P_{50}$ or $P_{88}$. The dataset comprised the water potential $(\Psi)$, the RWL (relative water loss) and the PLC (percent loss of conductivity)

\section{Discussion}

This study tested whether an empirical relationship between the loss of water transport capacity and the loss of water content could be established across temperate conifer species. We found that it was possible to predict conductivity loss and eventually $P_{50}$ or $P_{88}$ for different conifer species, organs, and age classes with a coefficient of determination of $94 \%$ from quite simple RWL and $\Psi$ measurements using one empirical model (conifer-curve, Fig. 3a). Although the RWL curves and the vulnerability curves differed widely between species, organs, or age classes (Fig. 2), the relationship between RWL and PLC is presumably quite conservative (Fig. 3). We discuss why this may be the case in conifers but not in angiosperms (Rosner et al. 2019), explore the relationship between hydraulic capacitance and vulnerability to cavitation, and propose how the technique could be further developed as a fast and reliable phenotyping tool.

\subsection{Why is the relationship between RWL and PLC so robust?}

Conifer wood is quite homogenously constructed and solely one-cell type, the tracheid, fulfills the different functions of water transport and mechanical support (Braun 1970; Lachenbruch and McCulloh 2014). Species, organ, or age class-specific variability in late wood percent, lumen diameter, cell wall thickness, tracheid length, and pit properties result in different hydraulic vulnerabilities and water release curves (Domec and Gartner 2001; Hacke et al. 2001; Domec et al. 2009; Bouche et al. 2014; Hacke et al. 2015). We found a wide range in $P_{50}$ values in the current study. In that regard, it was remarkable how the young trunk of $A$. nordmanniana saplings, with $P_{50}$ of $8.1 \mathrm{MPa}$ and trunk wood from the upper crown of mature $P$. abies trees with $P_{50}$ of $-2.2 \mathrm{MPa}$ (Fig. 4) could be fitted into one PLC-RWL curve (conifer-curve, Fig. 3a) from which the species- and age class-specific PLC at a given $\Psi$ could be reliably predicted from RWL data. This suggests that wood design in conifers is quite conservative concerning the PLC-RWL relationships. However, even if a given RWL results in a quite similar conductivity loss across different cambial age, anatomy can be adjusted to the hydraulic safety demands that are necessary for tree survival. The distance from the apex/tip influences tracheid size; tracheid lumen diameters are thus much smaller in saplings than at the lower trunk of mature trees of a given species (Anfodillo et al. 2013; Rosner 2017; Prendin et al. 2018); therefore, a stable PLC-RWL relationship suggests shorter tracheids and smaller pit aperture diameters with a higher torus overlap in saplings, which could additionally increase the hydraulic safety (Rosner 2013; Bouche et al. 2014; Hacke et al. 2015). Extreme shifts from the species mean PLC-RWL curve may come from the presence of 
Fig. 2 Point measurements of percent loss of hydraulic conductivity (PLC) and the estimated vulnerability curves described in Table 2 in the Annex (a, $\mathrm{c}, \mathrm{e}, \mathrm{g}$ ) and of relative water loss (RWL) and the estimated water loss curves described in Table 4 in the Annex (b, d, f, h) plotted against the water potential for different conifer species, organs or age classes
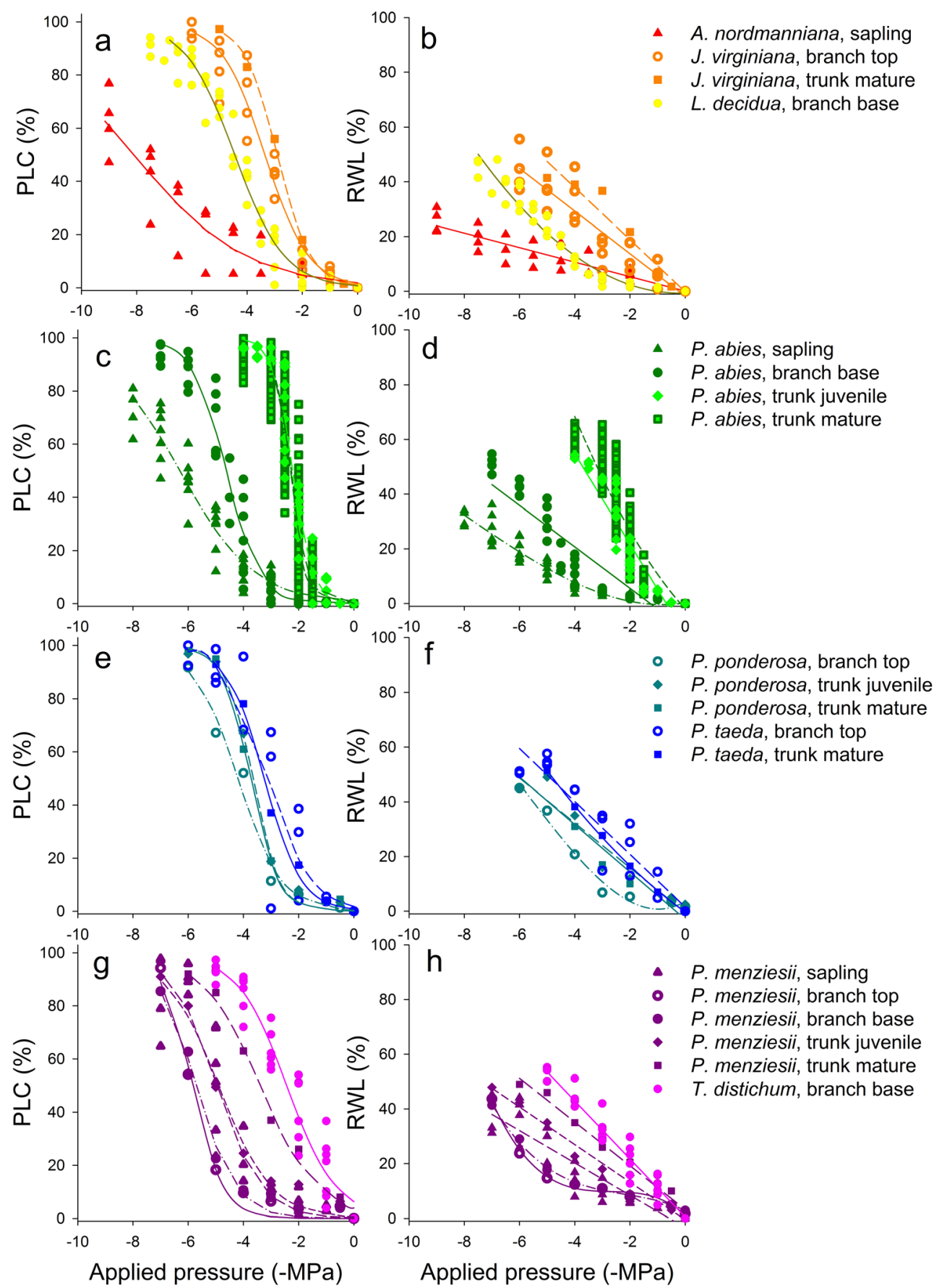

A. nordmanniana, sapling

J. virginiana, branch top

J. virginiana, trunk mature

L. decidua, branch base

Applied pressure (-MPa)

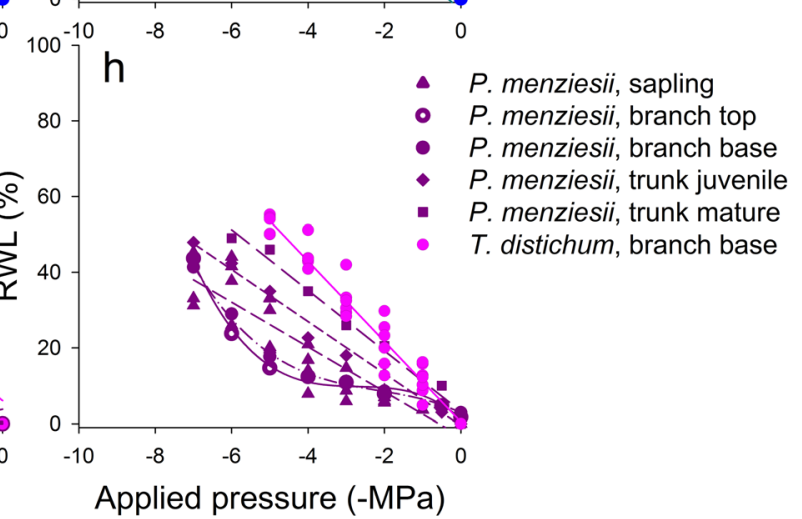

reaction wood. Compression wood (Fig. 7, in the Annex) has a high wood density, lower conductivity (Spicer and Gartner 1998), but is more vulnerable to cavitation than opposite wood (Mayr and Cochard 2003). For instance, L. decidua branches had a higher conductivity loss at given relative water loss compared with other species (Fig. 3a). RWL at $P_{50}$ was only $15.1 \%$. PLC in L. decidua predicted for a given $\Psi$ with the conifer-curve was lower than the measured PLC (Fig. 3c). Therefore, $P_{50}$ was lower (more negative) than the $P_{50}$ calculated from predicted PLC values of the species-specific L. decidua curves (Fig. 4).
Such shifts in the PLC-RWL curves result in different hydraulic capacities, thus in differences between RWL at $P_{50}$ or $P_{88}$.

\subsection{Relationship between hydraulic capacitance and vulnerability to cavitation}

Although the relationship between PLC and RWL is more stable in conifers than across angiosperm species (Rosner et al. 2019), species-, organ-, and age class-specific differences in the RWL at $P_{50}$ do exist (Fig. 5). The RWL at $P_{50}$ 

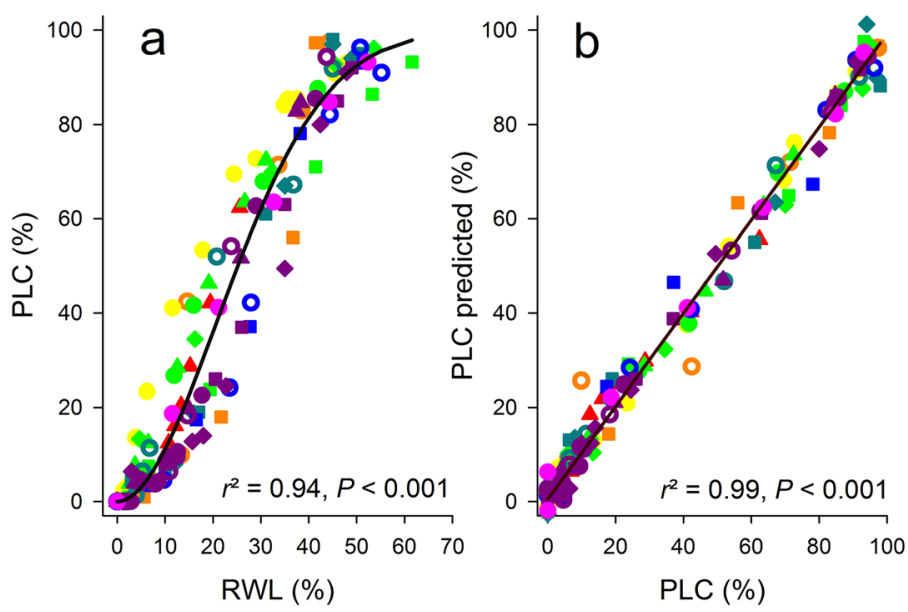

Fig. 3 Relationship between mean measured PLC and RWL across conifer species, organs and age classes for a given pressure application $(\Psi)$ : the "conifer-curve" (a), predicted mean PLC using species, organ and age specific curves (Table 3 in the Annex) (b) and predicted mean PLC using the "conifer-curve" (c) related both to mean measured PLC

can be regarded as a capacitance parameter (Rosner et al. 2019), which is very useful for comparing different species because no absolute values are used (Domec and Gartner 2001). We found a positive trend between $P_{50}$ and the RWL at $P_{50}$ and a significant positive relationship between $P_{50}$ and RWL at $P_{88}$ (Fig. 5). Similarly, McCulloh et al. (2014) found that mature conifer trunks had greater hydraulic vulnerability together with higher hydraulic capacitance than branches of the same species. Angiosperm branches with higher hydraulic capacitance also show less negative (higher) mean daily minimum water potentials (Meinzer et al. 2003). Species with higher $P_{50}$ may therefore have more pronounced diurnal changes in conductivity loss (Trifilò et al. 2015). Within a plant, woody parts with higher hydraulic vulnerability but higher hydraulic capacitance may act as important storage compartments for water (Holbrook 1995). We have no sound

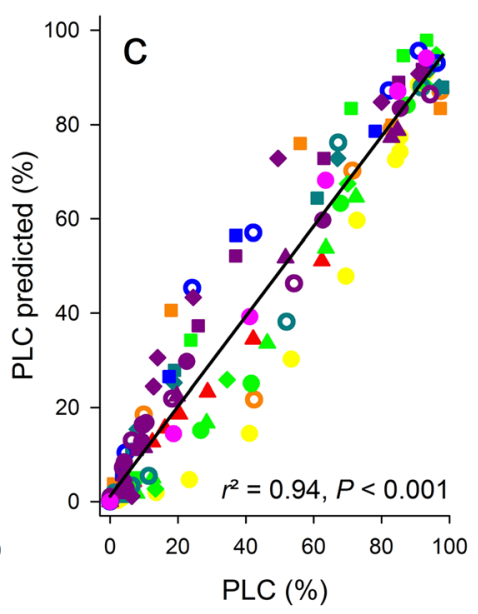

- A. nordmanniana, sapling

J. virginiana, branch top

I. virginiana, trunk mature

L. decidua, branch base

$P$. abies, sapling

$P$. abies, branch base

$P$. abies, trunk juvenile

- P. abies, trunk mature

- P. ponderosa, branch top

- P. ponderosa, trunk juvenile

- P. ponderosa, trunk mature

- P. taeda, branch top

- P. taeda, trunk mature

- P. menziesii, sapling

- P. menziesii, branch top

P. menziesii, branch base

- P. menziesii, trunk juvenile

- P. menziesii, trunk mature

- T. distichum, branch base

values at a given $\Psi$. The equation in plot (a) is as follows: $\mathrm{PLC}_{\mathrm{pred}}=100$ $\left(100 /\left(\exp \left((\mathrm{RWL} / c)^{* *} d\right)\right)\right)$, where $c$ is $30.49 \pm 0.52,95 \% \mathrm{CI}(29.4631 .52)$ and $d$ is $1.92 \pm 0.08,95 \%$ CI (1.75 2.08). Dataset number for all three plots is $n=147$

explanation why a stronger relationship existed between $P_{50}$ and RWL at $P_{88}$ than between $P_{50}$ and RWL at $P_{50}$, because in conifers, $P_{50}$ is regarded as a "point of no return" for the recovery from drought (Choat et al. 2018), even though some species can survive much lower conductivity losses (e.g., Hammond et al. 2019). It might be that the presence of reaction wood (Mayr and Cochard 2003) masks the relationship at high $\Psi$. The presence of reaction wood but also the distance from the apex/tip (Anfodillo et al. 2013; Rosner 2017; Prendin et al. 2018) may explain some different $P_{50}$ values than those found in literature. Branch $P_{50}$ values for $L$. decidua, P. abies, P. ponderosa, $P$. taeda, and $T$. distichum corresponded to those published earlier (reviewed in Choat et al. 2012, Bouche et al. 2014). We found however much higher (less negative) $P_{50}$ for $J$. virginiana branches but slightly lower $P_{50}$ in $P$. menziesii branches (reviewed in Choat et al. 2012).
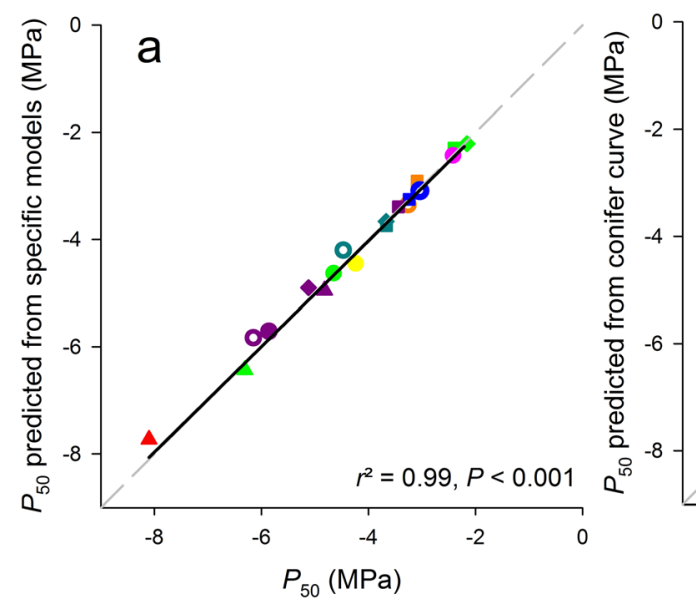

Fig. 4 Predicted pressure application that is necessary to result in $50 \%$ conductivity loss $\left(P_{50}\right)$ from species/organ/age specific models (Tables 2 , 3 , and 4 in the Annex) (a) and $P_{50}$ calculated from PLC predicted with the conifer-curve (eq. [4]) after slope correction (b) related to $P_{50}$ derived

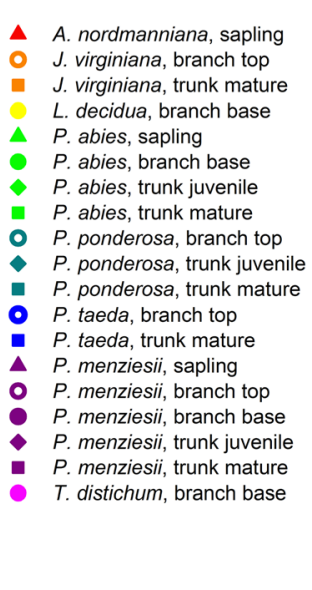

from experimental datasets. The slope correction (eq. [5]) was necessary because there was no 1:1 correlation (gray dashed lines) at lower $P_{50}$ values (Fig. 6 in the Annex) 

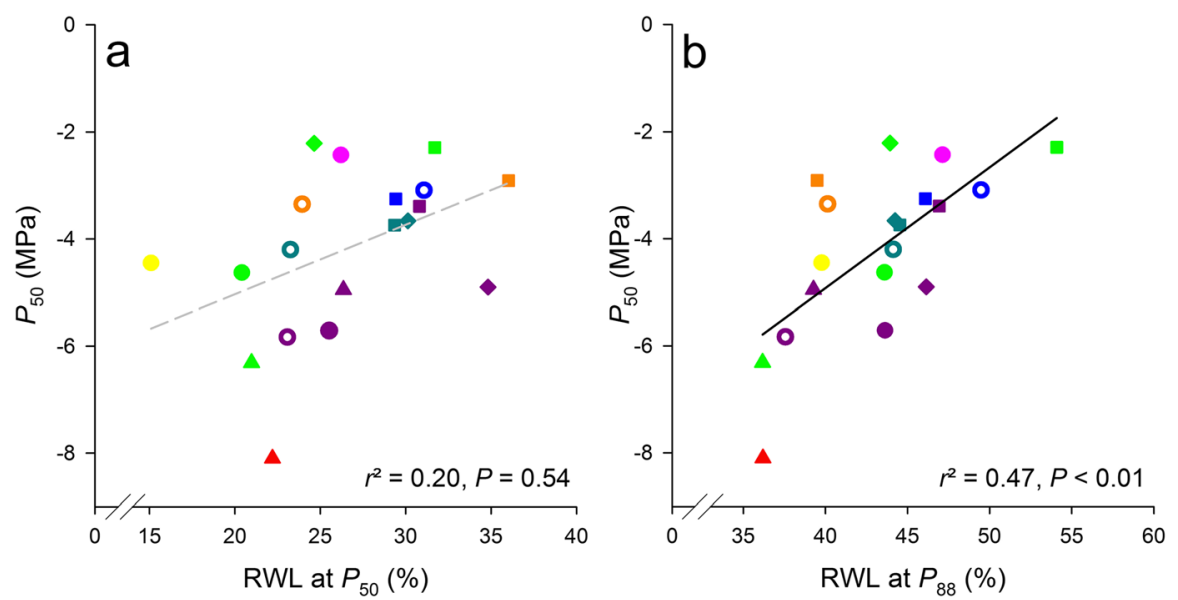

A. nordmanniana, sapling

- J. virginiana, branch top

J. virginiana, trunk mature

L. decidua, branch base

P. abies, sapling

P. abies, branch base

$P$. abies, trunk juvenile

$P$. abies, trunk mature

P. ponderosa, branch top

$P$. ponderosa, trunk juvenile

- P. ponderosa, trunk mature

- P. taeda, branch top

- P. taeda, trunk mature

- P. menziesii, sapling

- P. menziesii, branch top

P. menziesii, branch base

- P. menziesii, trunk juvenile

- P. menziesii, trunk mature

T. distichum, branch base

Fig. 5 Relationship between positive pressure that is necessary to result in $50 \%$ conductivity loss $\left(P_{50}\right)$ and the RWL at $P_{50}$ (a) and at $P_{88}$ (b) for different conifer species, organs and age classes

\subsection{Phenotyping: limits of application and further development of the method}

Note that the empirical models for predicting PLC from RWL measurements and eventually $P_{50}$ are applicable to functioning sapwood solely. In that regard, and except in Douglas-fir, the advantage of conifer wood is that many annual rings are used for conducting water (Bertaud and Holmbom 2004). However, reliable, standardized, sampling may be easier for wood of the main trunk than for small branches and shoots because the sapwood zone is easier to detect, and reaction wood can be avoided. However, when trunkwood is sampled, the distance from the apex/tip has to be considered (Anfodillo et al. 2013; Prendin et al. 2018). Even though branches used in general for vulnerability curves have a small diameter, they may be quite old (Schweingruber et al. 2008), and not all annual rings will necessarily transport water. It is thus important to harvest branches where the woody part consists of sapwood solely, which can be easily tested by staining techniques (Hietz et al. 2008). Moreover, we suggest performing experiments only during the growing season because (1) the bark is easier to remove from the woody parts, and (2) wood of temperate species harvested during the winter time shows a poorer ability to refill artificially, presumably because of natural pit aspiration (Mayr et al. 2014). The reliable prediction of the weight at full saturation is of utmost importance for the proposed technique, as already pointed out in a preceding study (Rosner et al. 2019). In a specimen that contains heartwood, the tracheids will not refill properly because many pits are permanently aspirated. Dehydration behavior of such "oversaturated" regions, i.e., artificially refilled regions that did not contribute to the sapflow in the living tree anymore (Pivovaroff et al. 2016), might be different. Moreover, the application of positive pressure may result in water loss but not necessarily to a loss in hydraulic conductivity.

The method presented is much less labor intensive than repeated flow measurements and less prone to errors resulting from tracheids clogged with resin or other organic substances.
Nevertheless, the procedure could still be improved, regarding the time that was necessary to measure one specimen. It should be possible to collect the xylem sap that is released due to the pressure application in pre-weighed vials (Ennajeh et al. 2011; Savi et al. 2019) and calculate the fresh weight at a given $\Psi$ from subtracting the mass of water. A whole vulnerability curve could thus be produced within less than a quarter of an hour. Consensus should be about the time of pressure application and the prepreparation of the specimens (Mayr et al. 2006), because this can influence the relationship between the RWL and $\Psi$. The method of stress application that leads to conductivity loss (e.g., bench top dehydration, pressure collar) has no influence on the relationship between RWL and PLC (Rosner et al. 2019), but for predicting $P_{50}, \Psi$-RWL datasets are necessary, which simulate the situation in the living tree. In that regard, it is likely that the conifer-curve is not applicable for RWL datasets of very small wood samples where $\Psi$ is measured in a small chamber of a thermocouple psychrometer (Meinzer et al. 2003; Barnard et al. 2011; McCulloh et al. 2014; Jupa et al. 2016; Pratt and Jacobsen 2017), because the curve shapes often differ from those measured on bigger samples (Domec and Gartner 2001, 2002; Domec et al. 2006; Gleason et al. 2014; Blackman et al. 2016). Due to the high amount of cut open surfaces in relation to volume, dehydration in small wood samples will proceed quite fast and probably not from the more vulnerable to the less vulnerable tracheids but from the outside to the inside of the specimen (Rosner et al. 2019).

\section{Conclusions}

We were able to construct one empirical model equation in order to predict conductivity loss and eventually $P_{50}$ for different conifer species originating from different ecosystems. The method offers fast and reliable prediction of PLC from quite simple and fast RWL and $\Psi$ measurements and could be thus applied as an efficient phenotyping tool for $P_{50}$. Future research should test this PLC-RWL in conifer species not included in this study to 
determine if the relationship is universal. The knowledge of this relationship can help interpret decent indirect anatomy-based techniques such as X-ray micro-computed tomography or neutron radiography. Future potential applications of the new method presented are screening trees for drought sensitivity and a fast interpretation of diurnal, seasonal, or drought-induced changes in xylem water content upon their impact on conductivity loss.

Acknowledgements We thank Helga Amreiter (Pötzleinsdorfer Schlosspark, Vienna, MA 42) for providing plant material of Taxodium distichum.

Statement on data availability The dataset for the "conifer-curve" is available from the corresponding author on reasonable request.

Funding Information Open access funding provided by University of Natural Resources and Life Sciences Vienna (BOKU). This study has received funding from the European Union's Horizon 2020 research and innovation program under the Marie Skłodowska-Curie grant agreement No 645654 (Topwood). DMJ was partially supported by NSF IOS-
165731 and JCD and DMJ were partially supported by NSF IOS1754893.

\section{Compliance with ethical standards}

Conflict of interest The authors declare that they have no conflict of interest.

Abbreviations CI 95\%, 95\% confidence intervals; DW, dry weight; FW, fresh weight; $P_{50}$, positive pressure resulting in $50 \%$ conductivity loss; $P_{50 \text { pred }}$, positive pressure resulting in $50 \%$ conductivity loss calculated from $\mathrm{PLC}_{\text {pred }} ; P_{50 \text { pred }}, P_{50 \text { pred }}$ after slope correction; $P_{88}$, positive pressure resulting in $88 \%$ conductivity loss; $P_{88 \text { pred }}$, positive pressure resulting in $88 \%$ conductivity loss calculated from $\mathrm{PLC}_{\text {pred }}$; PI $95 \%$, 95\% individual prediction intervals; PLC, percent loss of conductivity; $\mathrm{PLC}_{\text {pred }}$, PLC predicted from RWL; RWL, relative water loss; RWL at $P_{50}$, RWL at $\Psi$ when $50 \%$ conductivity is lost; RWL at $P_{88}$, RWL at $\Psi$ when $88 \%$ conductivity is lost; SW, water-saturated weight; $\Psi$, xylem pressure

\section{Annex}

Table 1 Information on the origin of the plant material, on the age of the trees (age), the amount of tree individuals investigated (tree), the sample numbers (sample) as well as the dataset numbers (data, i.e., single hydraulic measurements)

\begin{tabular}{|c|c|c|c|c|c|c|c|c|c|}
\hline Species & Origin & Lat. & Long. & $\begin{array}{l}\text { Alt. } \\
{[\mathrm{m}]}\end{array}$ & Age & Tree & Organ & Sample & Data \\
\hline Abies nordmanniana & $\begin{array}{l}\text { Botanical garden, } \\
\text { Vienna, Austria }\end{array}$ & $48^{\circ} 14^{\prime} 12^{\prime \prime}$ & $16^{\circ} 20^{\prime} 15^{\prime \prime}$ & 233 & 4 & 3 & Sapling & 4 & 27 \\
\hline Juniperus virginiana & $\begin{array}{l}\text { Duke Forest, Durham, } \\
\text { NC, USA }\end{array}$ & $35^{\circ} 97^{\prime} 82^{\prime \prime}$ & $-79^{\circ} 09^{\prime} 42^{\prime \prime}$ & 127 & 18 & 4 & Branch top & 4 & 28 \\
\hline Juniperus virginiana & $\begin{array}{l}\text { Duke Forest, Durham, } \\
\text { NC, USA }\end{array}$ & $35^{\circ} 97^{\prime} 82^{\prime \prime}$ & $-79^{\circ} 09^{\prime} 42^{\prime \prime}$ & 127 & 18 & 6 & Trunk mature & 6 & $7^{*}$ \\
\hline Larix decidua & $\begin{array}{l}\text { Botanical garden, } \\
\text { Vienna, Austria }\end{array}$ & $48^{\circ} 14^{\prime} 12^{\prime \prime}$ & $16^{\circ} 20^{\prime} 15^{\prime \prime}$ & 233 & 20 & 2 & Branch base & 8 & 52 \\
\hline Picea abies & $\begin{array}{l}\text { Botanical garden, } \\
\text { Vienna, Austria }\end{array}$ & $48^{\circ} 14^{\prime} 12^{\prime \prime}$ & $16^{\circ} 20^{\prime} 15^{\prime \prime}$ & 233 & 4 & 8 & Sapling & 8 & 54 \\
\hline Picea abies & $\begin{array}{l}\text { Botanical garden, } \\
\text { Vienna, Austria }\end{array}$ & $48^{\circ} 14^{\prime} 12^{\prime \prime}$ & $16^{\circ} 20^{\prime} 15^{\prime \prime}$ & 233 & 20 & 5 & Branch base & 6 & 46 \\
\hline Picea abies & Sande, Southern Norway & $59^{\circ} 34^{\prime} 50^{\prime \prime}$ & $10^{\circ} 16^{\prime} 29^{\prime \prime}$ & 105 & 40 & 6 & Trunk juvenile & 18 & 44 \\
\hline Picea abies & $\begin{array}{l}\text { Tönnersjöhëden/ } \\
\text { Vissefjärda, Sweden }\end{array}$ & $56^{\circ} 67^{\prime} / 56^{\circ} 54^{\prime}$ & $13^{\circ} 07^{\prime} / 15^{\circ} 53^{\prime}$ & $60 / 120$ & 24 & 44 & Trunk mature & 95 & 428 \\
\hline Pinus ponderosa & $\begin{array}{l}\text { Oregon Cascade Range, } \\
\text { Gilchrist, OR, USA }\end{array}$ & $43^{\circ} 32^{\prime} 25^{\prime \prime}$ & $-121^{\circ} 59^{\prime} 38^{\prime \prime}$ & 1355 & 225 & 6 & Branch top & 6 & $7 *$ \\
\hline Pinus ponderosa & $\begin{array}{l}\text { Oregon Cascade Range, } \\
\text { Gilchrist, OR, USA }\end{array}$ & $43^{\circ} 32^{\prime} 25^{\prime \prime}$ & $-121^{\circ} 59^{\prime} 38^{\prime \prime}$ & 1355 & 225 & 6 & Trunk juvenile & 6 & $7 *$ \\
\hline Pinus ponderosa & $\begin{array}{l}\text { Oregon Cascade Range, } \\
\text { Gilchrist, OR, USA }\end{array}$ & $43^{\circ} 32^{\prime} 25^{\prime \prime}$ & $-121^{\circ} 59^{\prime} 38^{\prime \prime}$ & 1355 & 225 & 6 & Trunk mature & 6 & $7 *$ \\
\hline Pinus taeda & $\begin{array}{l}\text { Duke Face experimental } \\
\text { site, Chapel Hill, } \\
\text { NC, USA }\end{array}$ & $35^{\circ} 58^{\prime} 39^{\prime \prime}$ & $-79^{\circ} 08^{\prime} 18^{\prime \prime}$ & 61 & 26 & 3 & Branch top & 3 & 18 \\
\hline Pinus taeda & $\begin{array}{l}\text { Duke Face experimental } \\
\text { site, Chapel Hill, } \\
\text { NC, USA }\end{array}$ & $35^{\circ} 58^{\prime} 39^{\prime \prime}$ & $-79^{\circ} 08^{\prime} 18^{\prime \prime}$ & 61 & 26 & 6 & Trunk mature & 6 & $6^{*}$ \\
\hline Pseudotsuga menziesii & $\begin{array}{l}\text { Botanical garden, Vienna, } \\
\text { Austria }\end{array}$ & $48^{\circ} 14^{\prime} 12^{\prime \prime}$ & $16^{\circ} 20^{\prime} 15^{\prime \prime}$ & 233 & 4 & 6 & Sapling & 6 & 36 \\
\hline Pseudotsuga menziesii & $\begin{array}{l}\text { Oregon Coast Range, } \\
\text { Riddle, OR, USA }\end{array}$ & $42^{\circ} 57^{\prime} 52^{\prime \prime}$ & $-123^{\circ} 21^{\prime} 76^{\prime \prime}$ & 220 & 116 & 6 & Branch top & 6 & $8^{*}$ \\
\hline Pseudotsuga menziesii & $\begin{array}{l}\text { Oregon Coast Range, } \\
\text { Riddle, OR, USA }\end{array}$ & $42^{\circ} 57^{\prime} 52^{\prime \prime}$ & $-123^{\circ} 21^{\prime} 76^{\prime \prime}$ & 220 & 116 & 6 & Branch base & 6 & $8^{*}$ \\
\hline Pseudotsuga menziesii & $\begin{array}{l}\text { Oregon Coast Range, } \\
\text { Riddle, OR, USA }\end{array}$ & $42^{\circ} 57^{\prime} 52^{\prime \prime}$ & $-123^{\circ} 21^{\prime} 76^{\prime \prime}$ & 220 & 116 & 6 & Trunk juvenile & 6 & $8^{*}$ \\
\hline Pseudotsuga menziesii & $\begin{array}{c}\text { Oregon Coast Range, } \\
\text { Riddle, OR, USA }\end{array}$ & $42^{\circ} 57^{\prime} 52^{\prime \prime}$ & $-123^{\circ} 21^{\prime} 76^{\prime \prime}$ & 220 & 116 & 6 & Trunk mature & 6 & $8^{*}$ \\
\hline Taxodium distichum & $\begin{array}{l}\text { Pötzleinsdorfer } \\
\text { Schlosspark, } \\
\text { Vienna, Austria }\end{array}$ & $48^{\circ} 14^{\prime} 33^{\prime \prime}$ & $16^{\circ} 18^{\prime} 21^{\prime \prime}$ & 233 & 20 & 3 & Branch base & 7 & 39 \\
\hline
\end{tabular}

Branches came either from the base of the crown (branch base) or from its top (branch top). Datasets are marked with * where only mean value datasets were available 
Table 2 Information on the hydraulic vulnerability curves fitted by an exponential sigmoidal equation (percent loss of conductivity $=100 /(1+$ $\exp .\left(a^{*}(\right.$ pressure- $\left.\left.\left.b)\right)\right)\right)($ Pammenter and VanderWilligen 1998)

\begin{tabular}{|c|c|c|c|c|c|}
\hline Species & $a$ & $P_{50}(\mathrm{MPa})$ & $r^{2}$ & $P$ & $P_{88}(\mathrm{MPa})$ \\
\hline Abies nordmanniana sapling & $0.49 \pm 0.07$ & $-8.10 \pm 0.25(-8.61-7.59)$ & 0.84 & $<0.0001$ & -12.14 \\
\hline Juniperus virginiana branch, top of canopy & $1.26 \pm 0.12$ & $-3.35 \pm 0.08(-3.52-3.19)$ & 0.96 & $<0.0001$ & -4.93 \\
\hline Juniperus virginiana trunk mature & $1.65 \pm 0.10$ & $-2.91 \pm 0.04(-3.01-2.80)$ & 0.99 & $<0.0001$ & -4.11 \\
\hline Larix decidua branch, base of canopy & $1.11 \pm 0.06$ & $-4.45 \pm 0.05(-4.55-4.34)$ & 0.97 & $<0.0001$ & -6.24 \\
\hline Picea abies sapling & $0.74 \pm 0.05$ & $-6.31 \pm 0.08(-6.46-6.15)$ & 0.93 & $<0.0001$ & -9.01 \\
\hline Picea abies branch, base of canopy & $1.62 \pm 0.15$ & $-4.63 \pm 0.06(-4.74-4.51)$ & 0.96 & $<0.0001$ & -5.85 \\
\hline Picea abies trunk juvenile & $2.86 \pm 0.27$ & $-2.21 \pm 0.03(-2.27-2.15)$ & 0.94 & $<0.0001$ & -2.91 \\
\hline Picea abies trunk mature & $3.44 \pm 0.13$ & $-2.29 \pm 0.01(-2.32-2.27)$ & 0.93 & $<0.0001$ & -2.87 \\
\hline Pinus ponderosa branch, top of canopy & $1.25 \pm 0.18$ & $-4.20 \pm 0.12(-4.51-3.89)$ & 0.98 & $<0.0001$ & -5.79 \\
\hline Pinus ponderosa trunk juvenile & $2.01 \pm 0.17$ & $-3.67 \pm 0.05(-3.79-3.54)$ & 0.99 & $<0.0001$ & -4.66 \\
\hline Pinus ponderosa trunk mature & $1.94 \pm 0.16$ & $-3.74 \pm 0.05(-3.87-3.61)$ & 0.99 & $<0.0001$ & -4.77 \\
\hline Pinus taeda branch, top of canopy & $1.29 \pm 0.31$ & $-3.09 \pm 0.21(-3.53-2.65)$ & 0.86 & $<0.0001$ & -4.64 \\
\hline Pinus taeda trunk mature & $1.50 \pm 0.12$ & $-3.25 \pm 0.06(-3.42-3.08)$ & 0.99 & $<0.0001$ & -4.58 \\
\hline Pseudotsuga menziesii sapling & $1.24 \pm 0.17$ & $-4.95 \pm 0.11(-5.18-4.72)$ & 0.90 & $<0.0001$ & -6.56 \\
\hline Pseudotsuga menziesii branch, top of canopy & $1.79 \pm 0.26$ & $-5.83 \pm 0.10(-6.05-5.62)$ & 0.99 & $<0.0001$ & -6.95 \\
\hline Pseudotsuga menziesii branch, base of canopy & $1.39 \pm 0.16$ & $-5.71 \pm 0.09(-5.92-5.49)$ & 0.99 & $<0.0001$ & -7.14 \\
\hline Pseudotsuga menziesii trunk juvenile & $1.04 \pm 0.12$ & $-4.90 \pm 0.12(-5.19-4.62)$ & 0.99 & $<0.0001$ & -6.82 \\
\hline Pseudotsuga menziesii trunk mature & $0.94 \pm 0.08$ & $-3.39 \pm 0.09(-3.63-3.15)$ & 0.99 & $<0.0001$ & -5.50 \\
\hline Taxodium distichum branch, base of canopy & $1.11 \pm 0.09$ & $-2.43 \pm 0.08(-2.59-2.27)$ & 0.95 & $<0.0001$ & -4.32 \\
\hline
\end{tabular}

The parameter " $a$ " corresponds to the slope of the linear part of the regression and " $b$ " is the $P_{50}$, i.e., the pressure that is necessary to result in $50 \%$ conductivity loss $P_{88}$ is the pressure that would result in $88 \%$ conductivity loss (Domec and Gartner 2001). Results for $a$ and $P_{50}$ are given with \pm standard error and the $95 \%$ confidence interval (CI 95\%) is given in brackets. Information on the sample and dataset numbers is given in Table 1 
Table 3 Parameters for linear $(b 0, b 1)$, quadratic $(b 0, b 1, b 2)$ or cubic $(b 0, b 1, b 2, b 3)$ equations for the relationship between percent loss of conductivity (PLC, independent variable) and the relative water loss (RWL, dependent variable) $(P<0.0001)$, the calculated RWL resulting

\begin{tabular}{|c|c|c|c|c|c|c|c|}
\hline Species and organ & $b 0$ & $b 1$ & $b 2$ & $b 3$ & $r^{2}$ & $\begin{array}{l}\text { RWL at } P_{50}(\mathrm{CI} 95 \%, \text { PI 95\%) } \\
(\%)\end{array}$ & $\begin{array}{l}\text { RWL at } P_{88}(\mathrm{CI} 95 \%, \text { PI 95\%) } \\
(\%)\end{array}$ \\
\hline Abies nordmanniana sapling & 3.7756 & 0.3684 & & & 0.89 & $22.20(20.3724 .02,15.6828 .71)$ & $36.19(32.5539 .84,28.9643 .43)$ \\
\hline $\begin{array}{l}\text { Juniperus virginiana branch, } \\
\text { top of canopy }\end{array}$ & 2.6466 & 0.4260 & & & 0.90 & $23.94(21.7626 .13,12.3035 .59)$ & $40.13(36.8243 .44,28.2252 .04)$ \\
\hline $\begin{array}{l}\text { Juniperus virginiana trunk } \\
\text { mature }\end{array}$ & 1.2356 & 1.4675 & -0.02030 & $9.735 \mathrm{E}-5$ & 0.99 & $36.02(33.3738 .62,27.4544 .59)$ & $39.49(35.3243 .65,31.4247 .55)$ \\
\hline $\begin{array}{l}\text { Larix decidua branch, } \\
\text { base of canopy }\end{array}$ & 1.3540 & 0.0617 & 0.00426 & & 0.98 & $15.09(14.4615 .71,10.6119 .57)$ & $39.77(38.7540 .79,35.2844 .26)$ \\
\hline Picea abies sapling & 0.9642 & 0.4001 & & & 0.94 & $20.97(19.9821 .96,15.4126 .54)$ & $36.17(34.2638 .09,30.3741 .97)$ \\
\hline $\begin{array}{l}\text { Picea abies branch, } \\
\text { base of canopy }\end{array}$ & 1.7912 & 0.3703 & -0.00147 & $3.028 \mathrm{E}-5$ & 0.98 & $20.41(19.6021 .21,15.0725 .74)$ & $43.60(42.3044 .89,38.3148 .88)$ \\
\hline Picea abies trunk juvenile & -0.7449 & 0.5076 & & & 0.96 & $24.64(23.5525 .72,17.4031 .87)$ & $43.93(42.2745 .59,36.5851 .27)$ \\
\hline Picea abies trunk mature & 2.2361 & 0.5892 & & & 0.96 & $31.70(31.3032 .20,22.2741 .13)$ & $54.09(54.5355 .82,44.6563 .53)$ \\
\hline $\begin{array}{l}\text { Pinus ponderosa branch, } \\
\text { top of canopy }\end{array}$ & 3.5165 & 0.0531 & 0.009710 & $-5.761 \mathrm{E}-5$ & 0.98 & $23.25(18.8627 .65,10.1436 .36)$ & $44.13(36.7051 .60,30.6057 .65)$ \\
\hline Pinus ponderosa trunk juvenile & 4.2940 & 0.5992 & -0.00165 & & 0.99 & $30.13(27.1133 .14,19.3240 .93)$ & $44.24(39.7148 .76,35.2053 .27)$ \\
\hline Pinus ponderosa trunk mature & 2.6332 & 0.6110 & -0.00153 & & 0.97 & $29.35(24.8133 .90,13.6045 .10)$ & $44.54(37.6851 .39,30.9358 .14)$ \\
\hline $\begin{array}{l}\text { Pinus taeda branch, top of } \\
\text { canopy }\end{array}$ & 6.8426 & 0.4846 & & & 0.92 & $31.07(27.9934 .15,17.7044 .44)$ & $49.48(45.0653 .90,35.7463 .23)$ \\
\hline Pinus taeda trunk mature & 0.9323 & 1.3476 & & & 0.99 & $29.42(29.2034 .54,17.8041 .03)$ & $46.09(38.9056 .30,35.5356 .66)$ \\
\hline Pseudotsuga menziesii sapling & 2.8286 & 0.5447 & -0.00148 & & 0.95 & $26.35(25.0827 .63,18.9933 .71)$ & $39.27(34.1341 .40,31.9546 .58)$ \\
\hline $\begin{array}{l}\text { Pseudotsuga menziesii } \\
\text { branch, top of canopy }\end{array}$ & 2.6957 & 1.0666 & -0.02050 & 0.000146 & 0.99 & $23.07(20.3625 .80,15.0931 .06)$ & $37.56(32.8042 .31,29.4945 .63)$ \\
\hline $\begin{array}{l}\text { Pseudotsuga menziesii } \\
\text { branch, base of canopy }\end{array}$ & 2.9799 & 1.0017 & -0.01744 & 0.000128 & 0.99 & $25.52(23.7527 .30,20.2730 .78)$ & $43.63(40.4546 .80,37.6349 .62)$ \\
\hline $\begin{array}{l}\text { Pseudotsuga menziesii } \\
\text { trunk juvenile }\end{array}$ & -1.4968 & 1.4887 & -0.02114 & 0.000118 & 0.99 & $34.82(31.8737 .78,25.0544 .60)$ & $46.14(41.0151 .28,36.6655 .62)$ \\
\hline $\begin{array}{l}\text { Pseudotsuga menziesii } \\
\text { trunk mature }\end{array}$ & 0.8228 & 1.0821 & -0.01399 & $8.696 \mathrm{E}-5$ & 0.99 & $30.81(29.3832 .23,26.2435 .38)$ & $46.93(44.6349 .24,42.4451 .42)$ \\
\hline $\begin{array}{l}\text { Taxodium distichum branch, } \\
\text { base of canopy }\end{array}$ & 1.1029 & 0.4746 & 0.00055 & & 0.97 & $26.21(25.0327 .39,18.6033 .82)$ & $47.13(45.3348 .93,39.5554 .71)$ \\
\hline
\end{tabular}

$P$ is $<0.0001$ for all equations listed in $50 \%$ (RWL at $P_{50}$ ) and $88 \%$ (RWL at $P_{88}$ ) of conductivity loss and their $95 \%$ confidence intervals (CI 95\%) and 95\% individual prediction intervals (PI 95\%) for different conifer species and different age classes 
Table 4 Relationship between pressure application and the relative water loss (RWL, independent variable) for the prediction of $P_{50}$

\begin{tabular}{|c|c|c|c|c|c|c|c|}
\hline Species and organ & $b 0$ & $b 1$ & $b 2$ & $b 3$ & $r^{2}$ & $P_{50 \text { pred }}(95 \%$ CI, $95 \%$ PI) (MPa) & $P_{88 \text { pred }}(95 \%$ CI, $95 \%$ PI) $(\mathrm{MPa})$ \\
\hline Abies nordmanniana sapling & -0.8447 & -0.3100 & & & 0.82 & $-7.73(-8.48-6.97,-10.50-4.95)$ & $-12.06(-13.54-10.59,-15.12-9.01)$ \\
\hline $\begin{array}{l}\text { Juniperus virginiana } \\
\text { branch, top of canopy }\end{array}$ & -0.6582 & -0.1088 & & & 0.85 & $-3.26(-3.58-2.95,-4.96-1.57)$ & $-5.03(-5.49-4.56,-6.76-3.30)$ \\
\hline Juniperus virginiana trunk & 0.0592 & -0.3141 & 0.0169 & -0.00029 & 0.99 & $-3.09(-3.49-2.70,-4.07-2.11)$ & $-4.13(-4.57-3.69,-5.03-3.22)$ \\
\hline $\begin{array}{l}\text { Larix decidua branch, } \\
\text { base of canopy }\end{array}$ & -1.0639 & -0.2530 & 0.0028 & & 0.91 & $-4.24(-4.45-4.04,-5.74-2.74)$ & $-6.68(-7.05-6.31,-8.19-5.17)$ \\
\hline Picea abies sapling & -0.4061 & -0.6779 & 0.0266 & -0.00040 & 0.95 & $-6.43(-6.63-6.22,-7.61-5.24)$ & $-8.15(-8.54-7.76,-9.54-6.76)$ \\
\hline $\begin{array}{l}\text { Picea abies branch, } \\
\text { base of canopy }\end{array}$ & -1.2307 & -0.2109 & 0.0021 & & 0.87 & $-4.65(-4.89-4.40,-6.35-2.95)$ & $-6.39(-6.83-5.98,-8.09-4.70)$ \\
\hline $\begin{array}{l}\text { Picea abies trunk wood } \\
\text { crown }\end{array}$ & -0.9150 & -0.0505 & & & 0.83 & $-2.16(-2.29-2.03,-3.02-1.30)$ & $-3.13(-3.33-2.94,-4.00-2.26)$ \\
\hline $\begin{array}{l}\text { Picea abies trunk wood } \\
\text { mature }\end{array}$ & -0.3351 & -0.0816 & 0.0005 & & 0.88 & $-2.40(-2.44-2.36,-3.27-1.54)$ & $-3.24(-3.30-3.18,-4.11-2.37)$ \\
\hline $\begin{array}{l}\text { Pinus ponderosa branch, } \\
\text { top of canopy }\end{array}$ & 0.9006 & 3.5165 & 0.0234 & -0.00029 & 0.96 & $-4.47(-5.31-3.62,-7.18-1.75)$ & $-5.89(-7.43-4.36,-8.65-3.13)$ \\
\hline $\begin{array}{l}\text { Pinus ponderosa trunk } \\
\text { juvenile }\end{array}$ & -0.3019 & -0.1118 & & & 0.92 & $-3.67(-4.41-2.93,-5.64-1.70)$ & $-5.25(-6.31-4.19,-7.36-3.14)$ \\
\hline $\begin{array}{l}\text { Pinus ponderosa trunk } \\
\text { mature }\end{array}$ & -0.5460 & -0.1062 & & & 0.92 & $-3.66(-4.39-2.95,-5.60-1.74)$ & $-5.28(-6.32-4.23,-7.34-3.21)$ \\
\hline $\begin{array}{l}\text { Pinus taeda branch, top of } \\
\text { canopy }\end{array}$ & -0.1886 & -0.0919 & & & 0.89 & $-3.04(-3.39-2.69,-4.57-1.52)$ & $-4.73(-5.23-4.24,-6.30-3.17)$ \\
\hline Pinus taeda trunk mature & -0.0690 & -0.1238 & 0.0006 & & 0.99 & $-3.24(-3.35-3.12,-3.55-2.92)$ & $-4.61(-4.79-4.44,-4.93-4.29)$ \\
\hline $\begin{array}{l}\text { Pseudotsuga menziesii } \\
\text { sapling }\end{array}$ & -1.0203 & -0.1440 & & & 0.85 & $-4.82(-5.17-4.46,-6.70-2.93)$ & $-6.68(-7.22-6.13,-8.60-4.75)$ \\
\hline $\begin{array}{l}\text { Pseudotsuga menziesii } \\
\text { branch, top of canopy }\end{array}$ & 1.2217 & -0.5071 & 0.0091 & -0.00004 & 0.98 & $-6.15(-6.73-5.57,-8.01-4.29)$ & $-7.17(-8.18-6.16,-9.38-4.95)$ \\
\hline $\begin{array}{l}\text { Pseudotsuga menziesii } \\
\text { branch, base of canopy }\end{array}$ & 1.9733 & -0.6419 & 0.0177 & -0.00018 & 0.99 & $-5.86(-6.24-5.47-6.99-4.74)$ & $-7.21(-7.97-6.46,-8.73-5.69)$ \\
\hline $\begin{array}{l}\text { Pseudotsuga menziesii } \\
\text { trunk juvenile }\end{array}$ & -0.1320 & -0.1432 & & & 0.98 & $-5.12(-5.48-4.76,-6.02-4.21)$ & $-6.74(-7.25-6.23,-7.71-5.76)$ \\
\hline $\begin{array}{l}\text { Pseudotsuga menziesii } \\
\text { trunk mature }\end{array}$ & 0.3430 & -0.1228 & & & 0.98 & $-3.44(-3.76-3.12,-4.33-2.55)$ & $-5.42(-5.91-4.93,-6.38-4.46)$ \\
\hline $\begin{array}{l}\text { Taxodium distichum } \\
\text { branch, base of canopy }\end{array}$ & 0.0498 & -0.0905 & & & 0.96 & $-2.42(-2.53-2.31,-3.14-1.70)$ & $-4.32(-4.49-4.14,-5.05-3.58)$ \\
\hline
\end{tabular}

Equation parameters are given either for linear $(b 0, b 1)$, quadratic $(b 0, b 1, b 2)$, or cubic $(b 0, b 1, b 2, b 3)$ equations for branches, saplings, or trunk wood of different conifer species. The predicted values of $P_{50}$ and $P_{88}$ are given with their $95 \%$ confidence intervals $(95 \% \mathrm{CI})$ and $95 \%$ prediction intervals $(95 \%$ PI). $P$ is $<0.0001$ for all equations listed 
Table 5 Information on the hydraulic vulnerability curves fitted by an exponential sigmoidal equation (percent loss of conductivity $=100 /(1+$ exp. $\left(a^{*}(\right.$ pressure- $\left.\left.\left.b)\right)\right)\right)($ Pammenter and VanderWilligen 1998)

\begin{tabular}{|c|c|c|c|c|c|}
\hline Species & $a$ & $P_{50 \text { pred }}(\mathrm{MPa})$ & $r^{2}$ & $P$ & $P_{88 \text { pred }}(\mathrm{MPa})$ \\
\hline Abies nordmanniana sapling & $0.41 \pm 0.06$ & $-9.01 \pm 0.37(-9.78-8.24)$ & 0.78 & $<0.0001$ & -13.92 \\
\hline Juniperus virginiana branch, top of canopy & $1.01 \pm 0.14$ & $-3.71 \pm 0.15(-4.02-3.41)$ & 0.89 & $<0.0001$ & -5.68 \\
\hline Juniperus virginiana trunk mature & $1.42 \pm 0.10$ & $-2.42 \pm 0.20(-2.93-1.90)$ & 0.97 & $<0.0001$ & -3.82 \\
\hline Larix decidua branch, base of canopy & $1.22 \pm 0.07$ & $-5.27 \pm 0.05(-5.37-5.16)$ & 0.97 & $<0.0001$ & -6.90 \\
\hline Picea abies sapling & $0.81 \pm 0.06$ & $-6.96 \pm 0.09(-7.14-6.77)$ & 0.91 & $<0.0001$ & -9.42 \\
\hline Picea abies branch, base of canopy & $1.84 \pm 0.17$ & $-4.87 \pm 0.05(-4.97-4.76)$ & 0.96 & $<0.0001$ & -5.95 \\
\hline Picea abies trunk juvenile & $3.18 \pm 0.37$ & $-2.33 \pm 0.04(-2.40-2.25)$ & 0.92 & $<0.0001$ & -2.95 \\
\hline Picea abies trunk mature & $4.10 \pm 0.13$ & $-2.16 \pm 0.01(-2.17-2.14)$ & 0.93 & $<0.0001$ & -2.64 \\
\hline Pinus ponderosa branch, top of canopy & $1.63 \pm 0.16$ & $-4.34 \pm 0.07(-4.52-4.16)$ & 0.99 & $<0.0001$ & -5.57 \\
\hline Pinus ponderosa trunk juvenile & $1.51 \pm 0.26$ & $-3.50 \pm 0.13(-3.83-3.17)$ & 0.98 & $<0.0001$ & -4.82 \\
\hline Pinus ponderosa trunk mature & $1.45 \pm 0.18$ & $-3.59 \pm 0.10(-3.84-3.34)$ & 0.99 & $<0.0001$ & -4.97 \\
\hline Pinus taeda branch, top of canopy & $1.09 \pm 0.25$ & $-2.52 \pm 0.21(-2.98-2.07)$ & 0.86 & $<0.0001$ & -4.35 \\
\hline Pinus taeda trunk mature & $1.27 \pm 0.08$ & $-2.85 \pm 0.06(-3.01-2.70)$ & 0.99 & $<0.0001$ & -4.42 \\
\hline Pseudotsuga menziesii sapling & $0.94 \pm 0.11$ & $-5.05 \pm 0.12(-5.30-4.80)$ & 0.89 & $<0.0001$ & -7.16 \\
\hline Pseudotsuga menziesii branch, top of canopy & $1.14 \pm 0.22$ & $-5.90 \pm 0.17(-6.32-5.49)$ & 0.96 & $<0.0001$ & -7.66 \\
\hline Pseudotsuga menziesii branch, base of canopy & $0.99 \pm 0.11$ & $-5.62 \pm 0.11(-5.89-5.35)$ & 0.99 & $<0.0001$ & -7.63 \\
\hline Pseudotsuga menziesii trunk juvenile & $0.81 \pm 0.09$ & $-4.01 \pm 0.14(-4.35-3.67)$ & 0.98 & $<0.0001$ & -6.46 \\
\hline Pseudotsuga menziesii trunk mature & $0.90 \pm 0.09$ & $-2.83 \pm 0.12(-3.13-2.53)$ & 0.99 & $<0.0001$ & -5.05 \\
\hline Taxodium distichum branch, base of canopy & $1.24 \pm 0.10$ & $-2.42 \pm 0.07(-2.57-2.27)$ & 0.95 & $<0.0001$ & -4.02 \\
\hline
\end{tabular}

PLC was derived from RWL by means of the "conifer-curve 1" [Eq. 4] presented in Fig. 2a. The parameter " $a$ " corresponds to the slope of the linear part of the regression and " $b$ " is the $P_{50}$, i.e., the pressure that is necessary to result in $50 \%$ conductivity loss. $P_{88}$ is the pressure that would result in $88 \%$ conductivity loss. Results for $a$ and $P_{50}$ are given with \pm standard error, and the $95 \%$ confidence interval (CI 95\%) is given in brackets. Information on the sample and dataset numbers is given in Table 1

Fig. 6 Predicted pressure application that is necessary to result in $50 \%$ conductivity loss $\left(P_{50}\right)$ from the conifer-curve 1 [Eq. 4] related to $P_{50}$ derived from experimental datasets. Detailed information on the predicted values can be found in Table 5 . The gray dashed line indicates the 1:1 relationship

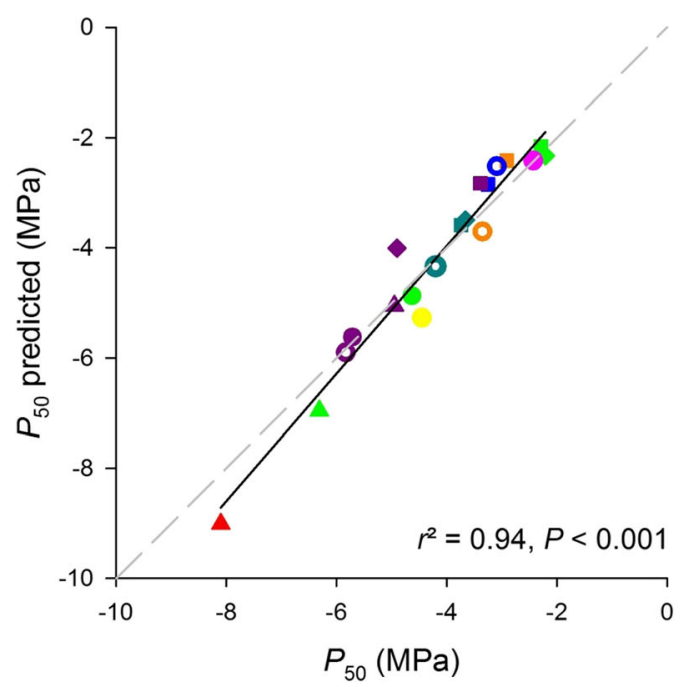

- A. nordmanniana, sapling

- J. virginiana, branch top

- J. virginiana, trunk mature

L. decidua, branch base

A $P$. abies, sapling

- $P$. abies, branch base

- $P$. abies, trunk juvenile

- $P$. abies, trunk mature

- P. ponderosa, branch top

- P. ponderosa, trunk juvenile

- P. ponderosa, trunk mature

- P. taeda, branch top

- P. taeda, trunk mature

A P. menziesii, sapling

- P. menziesii, branch top

- P. menziesii, branch base

- P. menziesii, trunk juvenile

- P. menziesii, trunk mature

- T. distichum, branch base 

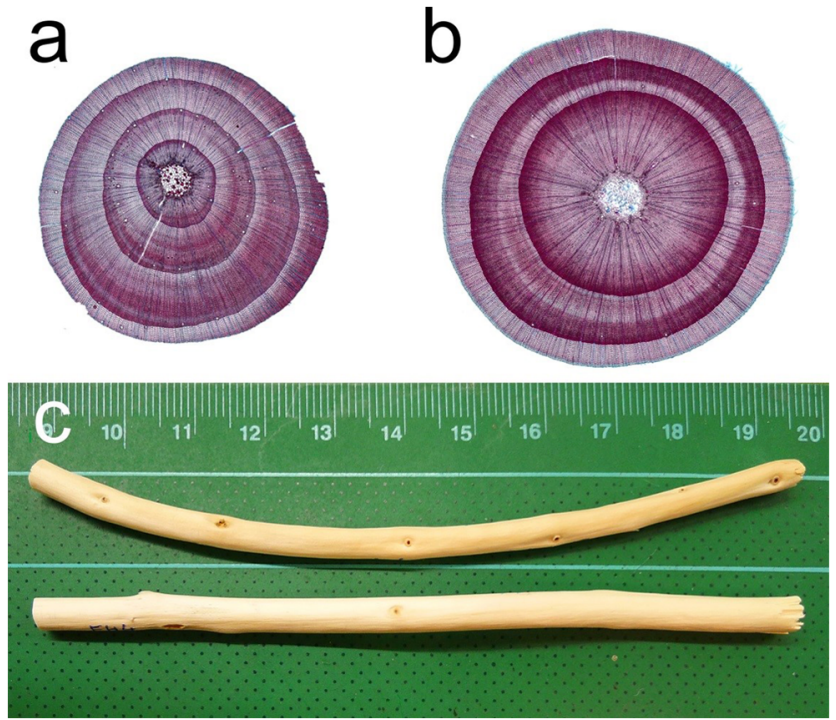

Fig. 7 Transverse sections of Larix decidua branch wood (a) and Picea abies young trunk wood (b). L. decidua contains compression wood that is common for conifers on the lower part of branches. Compression wood is characterized by higher density zones in the earlywood. Due to different shrinkage properties of wood differing in density, the $L$. decidua branch shows a concave bending at the compression wood side and a convex bending at the side of the opposite wood after drying at $103{ }^{\circ} \mathrm{C}$ (c, above), whereas it was straight at full saturation. The young trunk wood sample of a $P$. abies sapling remained straight after drying at $103^{\circ} \mathrm{C}$ because the amount of late wood was quite consistent in each annual ring (c, below)

Open Access This article is distributed under the terms of the Creative Commons Attribution 4.0 International License (http:// creativecommons.org/licenses/by/4.0/), which permits unrestricted use, distribution, and reproduction in any medium, provided you give appropriate credit to the original author(s) and the source, provide a link to the Creative Commons license, and indicate if changes were made.

\section{References}

Allen CD, Breshears DD, McDowell NG (2015) On underestimation of global vulnerability to tree mortality and forest die-off from hotter drought in the Anthropocene. Ecosphere 6:129. https://doi.org/10. 1890/ES15-00203.1

Anfodillo T, Petit G, Crivellaro A (2013) Axial conduit widening in woody species: a still neglected anatomical pattern. IAWA J 34: 352-364. https://doi.org/10.1163/22941932-00000030

Barnard DM, Meinzer FC, Lachenbruch B, McCulloh KA, Johnson DM, Woodruff DR (2011) Climate-related trends in sapwood biophysical properties in two conifers: avoidance of hydraulic dysfunction through coordination adjustment in xylem efficiency, safety and capacitance. Plant Cell Environ 34:634-654. https://doi.org/10. 1111/j.1365-3040.2010.02269.x

Bertaud F, Holmbom B (2004) Chemical composition of earlywood and latewood in Norway spruce heartwood, sapwood and transition zone wood. Wood Sci Technol 38:245-256. https://doi.org/10.1007/ s00226-004-0241-9

Blackman CJ, Pfautsch S, Choat B, Delzon S, Gleason SM, Duursma RA (2016) Toward an index of desiccation time to tree mortality under drought. Plant Cell Environ 39:2342-2345. https://doi.org/10.1111/ pce. 12758
Bouche PS, Larter M, Domec J-C, Burlett R, Gasson P, Jansen S, Delzon S (2014) A broad survey of hydraulic and mechanical safety in the xylem of conifers. J Exp Bot 65:4419-4431. https://doi.org/10. $1093 / \mathrm{jxb} / \mathrm{eru} 218$

Braun HJ (1970) Funktionelle Histologie der sekundären Sprossachse: I. Das Holz. Handbuch der Pflanzenanatomie IX/1. Gebrüder Borntraeger. Berlin Stuttgart

Choat B, Brodribb TJ, Brodersen CR, Duursma RA, Lopez R, Medlyn BE (2018) Triggers of tree mortality under drought. Nature 558: 531-539. https://doi.org/10.1038/s41586-018-0240-x

Choat B, Jansen S, Brodribb TJ, Cochard H, Delzon S, Bhaskar R, Bucci SJ, Feild TS, Gleason SM, Hacke UG, Jacobsen AL, Lens F, Maherali H, Martínez-Vilalta J, Mayr S, Mencuccini M, Mitchell PJ, Nardini A, Pitterman J, Pratt RB, Sperry JS, Westoby M, Wright IJ, Zanne AE (2012) Global convergence in the vulnerability of forests to drought. Nature 491:752-755. https://doi.org/10.1038/ nature 11688

Cochard H, Lemoine D, Améglio T, Granier A (2001) Mechanisms of xylem recovery from winter embolism in Fagus sylvatica. Tree Physiol 21:27-33. https://doi.org/10.1093/treephys/21.1.27

Cochard H, Badel E, Herbette S, Delzon S, Choat B, Jansen S (2013) Methods for measuring plant vulnerability to cavitation: a critical review. J Exp Bot 64:4779-4791. https://doi.org/10.1093/jxb/ert193

Delzon S, Cochard H (2014) Recent advances in tree hydraulics highlight the ecological significance of the hydraulic safety margin. New Phytol 203:355-358. https://doi.org/10.1111/nph.12798

Domec J-C, Gartner BL (2001) Cavitation and water storage in bole segments of mature and young Douglas-fir trees. Trees 15:204 214. https://doi.org/10.1007/s004680100095

Domec J-C, Gartner BL (2002) Age- and position-related changes in hydraulic versus mechanical dysfunction of xylem: inferring the design criteria for Douglas-fir wood structure. Tree Physiol 22:91104. https://doi.org/10.1093/treephys/22.2-3.91

Domec J-C, Scholz FG, Bucci SJ, Meinzer FC, Goldstein G, VillalabosVega R (2006) Diurnal and seasonal variation in root xylem embolism in neotropical savanna woody species: impact on stomatal control of plant water status. Plant Cell Environ 29:26-35. https://doi. org/10.1111/j.1365-3040.2005.01397.x

Domec J-C, Warren JM, Meinzer FC, Lachenbruch B (2009) Safety factors for xylem failure by implosion and air-seeding within roots, trunks and branches of young and old conifer trees. IAWA J 30: 100-120. https://doi.org/10.1163/22941932-90000207

Ennajeh M, Nouiri M, Khemira H, Cochard H (2011) Improvement to the air-injection technique to estimate xylem vulnerability to cavitation. Trees Struct Funct 25:705-710. https://doi.org/10.1007/s00468011-0548-8

Gleason SM, Blackman CJ, Cook AM, Laws CA, Westoby M (2014) Whole-plant capacitance, embolism resistance and slow transpiration rates all contribute to longer desiccation times in woody angiosperms from arid and wet habitats. Tree Physiol 34:275-284. https:// doi.org/10.1093/treephys/tpu001

Hacke UG, Lachenbruch B, Pitterman J, Mayr S, Domec J-C, Schulte PJ (2015) The hydraulic architecture of conifers. In: Hacke UG, ed. Functional and ecological xylem anatomy. Springer International Publishing Switzerland, 39-75

Hacke UG, Sperry JS, Pockman WT, Davis SD, McCulloh KA (2001) Trends in wood density and structure are linked to prevention of xylem implosion by negative pressure. Oecologia 126:457-461. https://doi.org/10.1007/s004420100628

Hammond WM, Yu KL, Wilson LA, Will RE, Anderegg WR, Adams HD (2019) Dead or dying? Quantifying the point of no return from hydraulic failure in drought-induced tree mortality. New Phytol (in press). https://doi.org/10.1111/nph.15922

Hentschel R, Rosner S, Kayler ZE, Andreassen K, Børja I, Solberg S, Tveito OE, Priesack GA (2014) Norway spruce physiological and 
anatomical predisposition to dieback. For Ecol Manag 322:27-36. https://doi.org/10.1016/j.foreco.2014.03.007

Hietz P, Rosner S, Sorz J, Mayr S (2008) Comparison of methods to quantify loss of hydraulic conductivity in Norway spruce. Ann For Sci 65:502-508. https://doi.org/10.1051/forest:2008023

Holbrook NM (1995) Stem water storage. In: Gartner BL (ed) Plant stem: physiology and functional morphology. Academic Press, San Diego, pp 157-174

IPCC (2013) Climate change 2013: the physical science basis. In: Stocker TF, Qin D, Plattner G-K, Tignor M, Allen SK, Boschung J, Nauels A, Xia Y, Bex V, Midgley PM (eds) Contribution of working group I to the fifth assessment report of the intergovernmental panel on climate change. Cambridge University press, Cambridge, New York, NY, p 1535

IUCN (2019) The IUCN red list of threatened species. Version 2018-2. http://www.iucnredlist.org. Accessed 26 January 2019

Johnson DM, McCulloh KA, Woodruff DR, Meinzer FC (2012) Hydraulic safety margins and embolism reversal in stems and leaves: why are conifers and angiosperms so different? Plant Sci 135:4-53. https://doi.org/10.1016/j.plantsci.2012.06.010

Jupa R, Plavcová L, Gloser V, Jansen S (2016) Linking xylem water storage with anatomical parameters in five temperate tree species. Tree Physiol 36:756-769. https://doi.org/10.1093/treephys/tpw020

Klein T, Zeppel MJ, Anderegg WR, Bloemen J, De Kauwe MG, Hudson P, Ruehr NK, Powell TL, von Arx G, Nardini A (2018) Xylem embolism refilling and resilience against drought-induced mortality in woody plants: processes and trade-offs. Ecol Res 33(5):839-855. https://doi.org/10.1007/s11284-018-1588-y

Klein T, Cahanovitc R, Sprintsin M, Herr N, Schiller G (2019) A nationwide analysis of tree mortality under climate change: Forest loss and its causes in Israel 1948-2017. For Ecol Manag 432:840-849. https://doi.org/10.1016/j.foreco.2018.10.020

Lachenbruch B, McCulloh KA (2014) Traits, properties, and performance: how woody plants combine hydraulic and mechanical functions in a cell, tissue, or whole plant. New Phytol 204:747-764. https://doi.org/10.1111/nph.13035

Lopez OR, Kursar TA, Cochard H, Tyree MT (2005) Interspecific variation in xylem vulnerability to cavitation among tropical tree and shrub species. Tree Physiol 25:1553-1562. https://doi.org/10.1111/ j.1469-8137.2007.02235.x

Magnani F, Borghetti M (1995) Interpretation of seasonal changes of xylem embolism and plant hydraulic resistance in Fagus sylvatica. Plant Cell Environ 18:689-696. https://doi.org/10.1111/j.13653040.1995.tb00570.x

Mayr S, Cochard H (2003) A new method for vulnerability analysis of small xylem areas reveals that compression wood of Norway spruce has lower hydraulic safety than opposite wood. Plant, Cell Environ 26: 1365-1371. https://doi.org/10.1046/j.0016-8025.2003.01060.x

Mayr S, Schmid P, Laur J, Rosner S, Charra-Vaskou K, Dämon B, Hacke UG (2014) Uptake of water via branches helps timberline conifers refill embolized xylem in late winter. Plant Physiol 164:1731-1740. https://doi.org/10.1104/pp.114.236646

Mayr S, Rothart B, Wolfschwenger M (2006) Temporal and spatial pattern of embolism induced by pressure collar techniques in twigs of Picea abies. J Exp Bot 57:3157-3163. https://doi.org/10.1093/jxb/ er1077

McCulloh KA, Johnson DM, Meinzer FC, Woodruff DR (2014) The dynamic pipeline: hydraulic capacitance and xylem hydraulic safety in four tall conifer species. Plant Cell Environ 37:1171-1183. https://doi.org/10.1111/pce.12225

McDowell NG, Allen CD (2015) Darcy's law predicts widespread forest mortality under climate warming. Nat Clim Chang 5:669-672. https://doi.org/10.1038/nclimate2641

Meinzer FC, James SA, Goldstein G, Woodruff DR (2003) Whole-tree water transport scales with sapwood capacitance in tropical forest canopy trees. Plant Cell Environ 26:1147-1155. https://doi.org/10. 1046/j.1365-3040.2003.01039.x

Mencuccini M, Binks O (2015) Tall, leafy conifers lose out. Nat Clim Chang 5:625-626. https://doi.org/10.1038/nclimate2698

Pivovaroff AL, Burlett R, Lavigne B, Cochard H, Santiago LS, Delzon S (2016) Testing the 'microbubble effect' using the Cavitron technique to measure xylem water extraction curves. AoB PLANTS 8:plw011. https://doi.org/10.1093/aobpla/plw011

Pammenter NW, VanderWilligen C (1998) A mathematical and statistical analysis of the curves illustrating vulnerability of xylem to cavitation. Tree Physiol 18:589-593. https://doi.org/10.1093/treephys/18. $8-9.589$

Pratt RB, Jacobsen AL (2017) Conflicting demands on angiosperm xylem: tradeoffs among storage, transport and biomechanics. Plant Cell Environ 40:897-913. https://doi.org/10.1111/pce.12862

Pratt RB, Jacobsen AL, Ewers FW, Davis SD (2007) Relationships among xylem transport, biomechanics and storage in stems and roots of nine Rhamnaceae species of the California chaparral. New Phytol 174:787-798. https://doi.org/10.1111/j.1469-8137.2007. 02061.x

Prendin AL, Mayr S, Beikircher B, von Arx G, Petit G (2018) Xylem anatomical adjustments prioritize hydraulic efficiency over safety as Norway spruce trees grow taller. Tree Physiol 38:1088-1097. https://doi.org/10.1093/treephys/tpy065

Rosner S (2013) Hydraulic and biomechanical optimization in Norway spruce trunkwood: a review. IAWA J 34:365-390. https://doi.org/ $10.1163 / 22941932-00000031$

Rosner S (2017) Wood density as a proxy for vulnerability to cavitation: size matters. J Plant Hydraulics 4:e001. https://doi.org/10.20870/ jph.2017.e001

Rosner S, Gierlinger N, Klepsch M, Karlsson B, Evans R, Lundqvist S-O, Světlík J, Børja I, Dalsgaard L, Andreassen K, Solberg S, Jansen S (2018) Hydraulic and mechanical dysfunction of Norway spruce sapwood due to extreme summer drought in Scandinavia. For Ecol Manag 409:527-540. https://doi.org/10.1016/j.foreco.2017.11.051

Rosner S, Heinze B, Savi T, Dalla-Salda G (2019) Prediction of hydraulic conductivity loss from relative water loss: new insights into water storage of tree stems and branches. Physiol Plant 165:843-854. https://doi.org/10.1111/ppl.12790

Rosner S, Klein A, Müller U, Karlsson B (2008) Tradeoffs between hydraulic and mechanical stress response of mature Norway spruce trunkwood. Tree Physiol 28:1179-1188. https://doi.org/10.1093/ treephys/28.8.1179

Savi T, Love VL, Dal Borgo A, Martellos S, Nardini A (2017) Morphoanatomical and physiological traits in saplings of drought-tolerant Mediterranean woody species. Trees 31:1137-1148. https://doi.org/ 10.1007/s00468-017-1533-7

Savi T, Tintner J, Da Sois L, Grabner M, Petit G, Rosner S (2019) The potential of mid-infrared spectroscopy for prediction of wood density and vulnerability to embolism in woody angiosperms. Tree Physiol (in press). https://doi.org/10.1093/treephys/tpy112

Scholz FG, Bucci SJ, Goldstein G, Meinzer FC, Franco AC, MirallesWilhelm F (2007) Biophysical properties and functional significance of stem water storage tissues in neotropical savanna trees. Plant Cell Environ 30:236-248. https://doi.org/10.1111/j.13653040.2006.01623.x

David-Schwartz R, Paudel I, Mizrachi M, Delzon S, Cochard H, Lukyanov V, Badel E, Capdeville G, Shklar G, Cohen S (2016) Indirect evidence for genetic differentiation in vulnerability to embolism in Pinus halepensis. Front Plant Sci 7:768. https://doi.org/10. 3389/fpls.2016.00768

Schweingruber FH, Börner A, Schulze E-D (2008) Atlas of woody plant stems: evolution, structure and environmental modifications. Springer-Verlag, Berlin Heidelberg 
Solberg S (2004) Summer drought: a driver for crown condition and mortality of Norway spruce in Norway. Forest Pathol 34:93-104. https://doi.org/10.1111/j.1439-0329.2004.00351.x

Sperry JS, Tyree MT (1988) Mechanism of water stress-induced xylem embolism. Plant Physiol 88:581-587

Spicer R, Gartner BL (1998) Hydraulic properties of Douglas-fir (Pseudotsuga menziesii) branches and branch halves with references to compression wood. Tree Physiol 18:777-784. https://doi.org/10. 1093/treephys/18.11.777

Trifilò P, Nardini A, Lo Gullo MA, Barbera PM, Savi T, Raimondo F (2015) Diurnal changes in embolism rate in nine dry forest trees: relationships with species-specific xylem vulnerability, hydraulic strategy and wood traits. Tree Physiol 35:694-705. https://doi.org/ 10.1093/treephys/tpv049
Tyree MT, Yang S (1990) Water-storage capacity of Thuja, Tsuga and Acer stems measured by dehydration isotherms. Planta 182:420 426. https://doi.org/10.1007/BF02411394

Tyree MT, Sperry JS (1988) Do woody plants operate near the point of catastrophic xylem dysfunction caused by dynamic water stress? Answers from a model. Plant Physiol 88:574-580

Voltas J, Shestakova TA, Patsiou T, Di Matteo G, Klein T (2018) Ecotypic variation and stability in growth performance of the thermophilic conifer Pinus halepensis across the Mediterranean basin. Forest Ecol Managem 424:205-215. https://doi.org/10.1016/j. foreco.2018.04.058

Publisher's note Springer Nature remains neutral with regard to jurisdictional claims in published maps and institutional affiliations. 